\title{
Expression of TLR-22 Gene and Response of Non Specific Immunity of Labeo rohita Fed with Fucoidan Rich Seaweed Extract in Conjugation with Bacillus subtilis
}

\author{
R. Ghoshal* and N.P. Sahu \\ Department of Fish Nutrition, Physiology and Biochemistry, ICAR-Central Institute of \\ Fisheries Education, Mumbai, India \\ *Corresponding author
}

\section{A B S T R A C T}

\section{Keywords}

Fucoidan, Probiotic, Non specific immunity, $A$. hydrophila

Article Info

Accepted:

04 October 2019

Available Online:

10 November 2019
A 60-days feeding trial was conducted to study the combined effect of fucoidan rich seaweed extract (FRSE) from Sargassum wightii and probiotic (Bacillus subtilis) on expression of TLR22 gene in Labeo rohita fingerlings. Two hundred and ten fingerlings of uniform size group were distributed into seven experimental groups in triplicates. Each tank was stocked with ten fish and fed to satiation with isonitrogenous (35.33-35.6 CP\%) and iso-caloric (393.33 to $399.43 \mathrm{Kcal} / 100 \mathrm{~g})$ purified diets containing 0\% FRSE and no probiotic (control), 2\% FRSE (T1), $10^{8} \mathrm{CFU} \mathrm{g}{ }^{-1}$ probiotic (T2), $1 \%$ FRSE $+10^{5} \mathrm{CFU} \mathrm{g}{ }^{-1}$ probiotic (T3), $2 \%$ FRSE $+10^{5} \mathrm{CFU} \mathrm{g}{ }^{-1}$ probiotic (T4), $1 \%$ FRSE $+10^{8} \mathrm{CFU} \mathrm{g}^{-1}$ probiotic (T5) and $2 \% \mathrm{FRSE}+10^{8} \mathrm{CFU} \mathrm{g} \mathrm{g}^{-1}$ probiotic (T6). After feeding trial, the experimental fish were challenged with Aeromonas hydrophila. Expression of TLR22 gene was studied in the liver and recorded significantly higher in T6 group in pre-challenge condition whereas both T6 and $\mathrm{T} 4$ groups during post-challenge condition. Total leucocyte count were estimated and recorded significantly higher $(\mathrm{p}<0.05)$ in treatment groups compared to the control with highest values in T6 group whereas albumin/globulin $(\mathrm{A} / \mathrm{G})$ ratio exhibited decreasing trend in the treatment groups. These results suggested that addition of probiotic at $10^{5}$ or $10^{8} \mathrm{CFU} \mathrm{\textrm {g } ^ { - 1 }}$ dosage with $2 \%$ FRSE act synergistically and enhanced the non specific immunity of $L$. rohita fish effectively.

\section{Introduction}

Seaweeds or marine algae constitute one of the commercially important renewable marine living resources. They are the only source for the production of phytochemicals such as agar, carrageenan and sodium alginate, which are widely used as gelling, stabilizing and thickening agents in food, confectionary and pharmaceutical. Marine seaweeds are also used in different parts of the world as animal feed and fertilizer for land crops as well as aquatic animals as they contain more than 60 trace elements, carbohydrate, iodine, bromine, 
vitamins and some bioactive substances (Silas et al., 1986; Kaliaperumal, 1993).

Several phytochemicals have already been used in animal feeds as immunomodulators. Fucoidans are polysaccharides containing substantial percentages of L-fucose and sulfate ester groups. Fucoidans (sulphated polysaccharides), which are constituents of brown seaweeds and some marine invertebrates such as sea urchins and sea cucumbers, demonstrate a variety of pharmaceutically relevant biological activities including anticoagulant and antithrombotic, antivirus, antitumor and immunomodulatory, anti-inflammatory, antioxidant and anticomplementary properties (Lee et al., 2004; Zhuang et al., 1995).

Rohu (Labeo rohita) is an important fish among the three Indian major carp species used in carp polyculture systems. Rohu is the principal species reared in carp polyculture. Due to its wider feeding niche, which extends from column to bottom, rohu is usually stocked at relatively higher levels than the other two species. The higher consumer preference and market demand for rohu during recent years have led to its intensive farming. The intensive farming of rohu has without doubt created a stressful condition due to very high stocking densities along with vagaries weather conditions especially temperature. Therefore, to safeguard fishes from microbial infection and increased production, the animal should be fed with an ideal, potential and cost effective feed, which can improve their nonspecific defence mechanism against pathogens.

Although, fucoidan is a well-known immunostimulant for fish, the economic feasibility of this fucoidan depends upon its minimum inclusion level as maximum 5\% recovery of fucoidan has been reported from different seaweeds. Hence, a synergistic effect of fucoidan with any other additive which can stimulate immunity at lower dose is also a researchable issue. Moreover, the anti bacterial activity of fucoidan may inhibit some of the beneficial bacteria in the fish gut, hence if it is supplied to fish in conjugation with probiotic it may result better towards strengthening the innate immunity of target species.

\section{Materials and Methods}

\section{Site of the experiment}

The experiment was conducted over a period of 60 days at the Wet Laboratory of Central Institute of Fisheries Education (CIFE) in Seven Bunglows Campus, Mumbai. The experimental set up was maintained in triplicate and sampling, proximate analysis, biochemical and molecular work was carried out in the Fish Nutrition and Biochemistry Laboratory.

\section{Experimental animal}

Fingerlings of rohu, Labeo rohita with an average weight of $6-8 \mathrm{~g}$ were used for the experimental purpose. The fishes were procureded from Prem Fisheries Consultancy, Ankleshwar, Gujarat. The fishes were packed in airtight bags and transported to CIFE, Wet Laboratory. They were carefully transferred to circular tanks of 400L capacity with vigorous aeration. The fish were left undisturbed the overnight. In order to ameliorate the handling stress the fish were given $0.2 \%$ salt treatment for 2 minutes in the next morning. The stock was acclimatized under aerated conditions and fed with $35 \%$ crude protein diet.

\section{Experimental design and set-up}

The experiment was conducted over a period of 60 days at the Wet Laboratory of Central Institute of Fisheries Education (CIFE). Total 
experiment was conducted in 21 plastic rectangular tubs $(80 \times 57 \times 42 \mathrm{~cm}, \quad 100 \mathrm{~L}$ capacity) covered with plastic lids. The tubs were initially washed with potassium permanganate solution $(5 \mathrm{mg} / \mathrm{ml})$ and were left overnight. The tanks were flushed out on the next day and then thoroughly washed with water. About 210 fingerlings were randomly distributed in the five distinct experimental groups with each of three replicates. Ten fishes with initial weight of 6 to $8 \mathrm{~g}$ were stocked in each of the tubs with $80 \mathrm{~L}$ chlorine free water.

\section{Rearing}

The fishes of uniform size were kept in each tub. Each tub was covered with a lid to prevent the fish from jumping out. No attempts were made to stimulate or control the environmental condition. The experimental conditions were kept the same all throughout the experimental period. The body weight was measured at 15 days interval to assess the growth. The fishes were starved overnight before taking the bodyweight.

\section{Cleaning and siphoning}

The experimental tanks were cleaned manually and siphoning was done every day in order to remove left out feed pellets and the faecal matter to prevent deterioration of water quality. An equal volume of clean bore well water maintained at the same temperature was used to replace the siphoned out water. This was carried out throughout the experimental period.

\section{Fucoidan}

Fucoidan is a polysaccharide containing Lfucose along with glucuronic acid and xylose. Fucoidan is a high molecular weight, water soluble polysaccharide and has a molecular weight of more than $20 \mathrm{KDa}$. The function of fucoidan is to protect the intertidal seaweeds against dehydration. Besides it also helps to enhance cell wall stability and involved in the morphogenesis of algae embryos ( $\mathrm{Vo}$ and Kim, 2013).

\section{Seaweed collection}

Sargassum wightii, a brown seaweed, has used in this study. It was collected from Mandapam, Ramanathapuram district of Tamil Nadu. Seaweed samples were collected from the sea with the help of fishermen. Then from the heaps, the species required for the experiment was sorted out, the sample of the species was brought to the CMFRI centre, Mandapam and identified and confirmed by scientists of CMFRI, Mandapam.

\section{Fucoidan extraction (Alcohol-water method)}

Freshly collected mature, disease free and healthy brown seaweed was thoroughly washed with water to remove all the dirt and other extraneous materials adhering to it. The seaweed was then shade dried for two days to make it completely dry. The dried seaweed was then ground and made into fine powder.

One kilogram of fresh seaweeds yields $100 \mathrm{~g}$ of dried powder. The fine powder weighing $100 \mathrm{~g}$ was then taken in an appropriate sized vessel and $1000 \mathrm{ml}$ of $85 \%$ ethanol was added to it, followed by overnight stirring at room temperature. The next day, the alcohol was decanted and the residual seaweed was washed with acetone. The acetone was decanted and residual seaweed was centrifuged at $10000 \mathrm{rpm}$ for $15 \mathrm{~min}$. The supernatant obtained was discarded. The residual seaweed was dried at room temperature overnight to remove the residual acetone. The seaweed was mixed with $1000 \mathrm{ml}$ of distilled water and stirred for $7 \mathrm{hrs}$ at $70^{\circ} \mathrm{C}$. The hot mixture was filtered with a muslin cloth. The residual seaweed was again mixed with $500 \mathrm{ml}$ of water and stirred for $7 \mathrm{hrs}$ at 
$70^{\circ} \mathrm{C}$. Again the water was filtered out with a muslin cloth. Both the extracts were pooled together. The extract was then centrifuged at $10000 \mathrm{rpm}$ for $15 \mathrm{~min}$. The supernatant was collected. Calcium chloride pellets were then added to the supernatant to make the concentration to $1 \%$ of the extract, followed by vigorous mixing. The extract was stored at $4^{\circ} \mathrm{C}$ overnight. The next day, the precipitated alginates were filtered out and the dark orange brown aliquot was obtained which was crude fucoidan extract.

\section{Purification of fucoidan}

Crude fucoidan was purified by using dialysis membrane. The membrane was activated before use by boiling it in $1 \mathrm{mM}$ EDTA solution for $10 \mathrm{~min}$. Then, the crude fucoidan was put inside the dialysis tube whose both ends were closed by a thread. The tubing was then kept in a $2 \mathrm{~L}$ beaker with distilled water and the water was stirred using magnetic stirrer at room temperature. The water was replaced regularly as per the saturated level of impurities exuding from the tubing. This was done for $24 \mathrm{hrs}$ until there was no visible impurity. The product which was purified fucoidan was used for fucoidan yield quantification and study of antioxidant properties.

\section{Quantification of fucoidan}

The dialysed sample was used for quantification. L-fucose content was analysed by method of Dubois et al., (1956). Two millilitre of purified extract was pipetted into calorimetric tube and $50 \mu 1$ of $80 \%$ phenol was added followed by $5 \mathrm{ml}$ of concentrated sulphuric acid. The stream of acid was directed into the liquid surface rather than the walls of the test tube in order to facilitate good mixing. The tube was allowed to stand for 10 min and then kept at $37^{\circ} \mathrm{C}$ for half an hour. The absorbance of the characteristic orange yellow colour was measured against the blank reagent at $480 \mathrm{~nm}$. L-fucose was taken as the standard. From the L-fucose content the fucoidan yield was calculated by using 1.75 , which was obtained theoretically that, Lfucose is present approximately at $60 \%$ in fucoidan.

\section{Methods of screening antioxidant property: Estimation of DPPH scavenging}

DPPH scavenging activity of crude fucoidan extract was measured by modified method of Brand-Williams et al., (1995). The DPPH (2,2-diphenyl-1-picrylhydrozyl) radical has a deep purple colour. The purple chromogen radical is reduced by antioxidant/reducing compound to the corresponding pale yellow hydrazine. The fucoidan sample with different concentrations was taken and then $2 \mathrm{ml}$ of 0.06M methanolic DPPH was added. Then it was mixed well and kept in dark for $30 \mathrm{~min}$. Then the OD value was measured at $517 \mathrm{~nm}$ against the reagent blank. The control containing no fucoidan extract was also run along with the samples.

\section{Bacterial strain and culture}

The pure bacterial isolate of Bacillus subtilis (MTCC No. 10407) was received from Microbial Type Culture Collection and Gene Bank (MTCC), Chandigarh as lyophilized cells and was maintained at $4^{0} \mathrm{C}$.

Subsequently, the bacteria was inoculated into conical flask containing nutrient broth (HiMedia) and kept in BOD incubator for $24 \mathrm{~h}$ at $30^{\circ}$ C. After which a loopful of bacterial culture was streaked on Nutrient agar (HiMedia) plate. The bacterial colonies, which grew on the Nutrient agar, after $24 \mathrm{~h}$ of incubation at $30^{\circ} \mathrm{C}$, were confirmed as pure isolates of respective culture by performing the essential biochemical tests and were used for mass culture for subsequent use in the experiment. 


\section{Quantification of inoculums}

To determine the concentrations of the bacterial inoculums to be added into the feed for the experiment, bacteria was streaked on nutrient broth and incubated for $12 \mathrm{~h}$ at $37^{\circ} \mathrm{C}$. One freshly grown colony was picked and transferred into $50 \mathrm{ml}$ of nutrient broth, and incubated under the same conditions for $4 \mathrm{~h}$. A second transfer was carried out into $100 \mathrm{ml}$, under same conditions. Then optical density (OD) at $600 \mathrm{~nm}$ was recorded, simultaneously serial dilutions were performed for each hour. The dilutions were plated onto the nutrient agar by spread plate technique. After $12 \mathrm{~h}$ of incubation at $28^{\circ} \mathrm{C}$ colonies were counted. The data were related in graphs, obtaining the relationship CFU vs. $\mathrm{OD}_{600}$ vs. time.

\section{Experimental diets}

Purified experimental diets were prepared so as to keep the crude protein level and lipid level at 35\% and $8 \%$ respectively (Table 1 ).

\section{Formulation and preparation of experimental diets}

Purified ingredients were used to prepare the diets. The ingredients were brought from Himedia chemical Ltd. Seven diets of same composition except the cellulose, fucoidan and probiotic were prepared in the Fish Nutrition Laboratory of CIFE. The cellulose powder was used as filler to make up the volume as equal quantity in all the diets. The diets were control(C), 2\%fucoidan rich seaweed extract (FRSE) (T1), Bacillus subtilis $10^{8} \mathrm{CFU} \mathrm{g}^{-}$ ${ }^{1}$ (T2), $1 \%$ FRSE + Bacillus subtilis $10^{5} \mathrm{CFU}$ $\mathrm{g}^{-1}$ (T3), 2\% FRSE + Bacillus subtilis $10^{5}$ CFU g ${ }^{-1}(\mathrm{~T} 4), 1 \%$ FRSE + Bacillus subtilis $10^{8}$ CFU g ${ }^{-1}$ (T5) and 2\% FRSE + Bacillus subtilis $10^{8} \mathrm{CFU} \mathrm{g}^{-1}$ (T6) respectively.

All the ingredients were weighed as per the requirements. Gelatin was first mixed with luke warm water and then added with the rest of the ingredients. The ingredients were then properly mixed and dough was made with the addition of water. After the dough was made, it was transferred to autoclave for steaming. The steaming was done for half an hour. The cooked dough was removed and the lipid, vitamin mineral premix and the viscous crude fucoidan extract was added and mixed properly. Quantified bacterial cells present in the broth was sprayed uniformly as per the need and mixed. The feed was then pelletized using the automatic pelletizer. The moist pellets were collected on a paper and then left for shade drying for one day. The next day the dried pellets were manually crumbled and packed in airtight containers.

\section{Proximate composition of fish and diets}

The fishes were collected from the experimental tubs and the biomass of the respective tubs was noted down. The samples were then stored at $0^{\circ} \mathrm{C}$ for conducting the proximate analysis. It was done by prescribed method (AOAC, 1995) in the Fish Nutrition Laboratory of CIFE.

\section{Gene expression study}

\section{Tissue collection and preservation}

The sampling was done on $45^{\text {th }}$ day of feeding trial and $15^{\text {th }}$ day of challenge by $A$. hydrophila. The organs were collected carefully using sterile scissors and forceps. Each specimen was preserved in RNAlater (QIAGEN, USA) for further use.

\section{Total RNA isolation}

Total RNA was isolated from tissue samples (liver) of different treatment groups of Labeo rohita using Trizol ${ }^{\mathrm{TM}}$ reagent (Invitrogen, USA) according to the manufacturer's protocol. The samples $(50 \mathrm{mg})$ were taken in 
$2.0 \mathrm{ml}$ homogenization tubes containing glass beads and homogenized in $1 \mathrm{ml}$ Trizol $^{\mathrm{TM}}$ reagent using Micro Smash MS-200 (Tomy, Japan) for 20-30s at $4000 \mathrm{rpm}$. The homogenate was incubated for $10 \mathrm{~min}$ at room temperature to allow lysis followed by addition of $200 \mu \mathrm{l}$ of chloroform with vigorous mixing resulting in no separate layers. It was then incubated for 2-3 $\mathrm{min}$ at room temperature. The sample was centrifuged at $12,000 \mathrm{rpm}$ for $10 \mathrm{~min}$ at $4^{\circ} \mathrm{C}$. The upper aqueous layer containing RNA was transferred carefully into a fresh $1.5 \mathrm{ml}$ micro centrifuge tube containing $500 \mu \mathrm{l}$ of isopropanol and incubated for 10-15 min at room temperature for precipitation of RNA. The sample was then centrifuged at 12000 rpm for $10 \mathrm{~min}$ at $4^{\circ} \mathrm{C}$ to get the RNA pellet. The RNA pellet was washed twice with $75 \%$ ethanol (chilled) and was centrifuged at 12000 $\times \mathrm{g}$ for $2 \mathrm{~min}$ at $4^{\circ} \mathrm{C}$. The pellet was air dried to remove residual ethanol and subsequently dissolved in $30 \mu \mathrm{l}$ of nuclease free water. To facilitate dissolution of pellet the tubes were kept at $55^{\circ} \mathrm{C}$ for $10 \mathrm{~min}$ in a water bath. The RNA was then stored at $-80^{\circ} \mathrm{C}$ until used for cDNA synthesis. The concentration of the isolated RNA was measured using Nanodrop spectrophotometer (Thermo Scientific, USA). Nucleic acid concentration was obtained directly in terms of $\mathrm{ng} / \mu \mathrm{l}$ along with the 260:280 ratios. The ratio of the absorbance at $260 \mathrm{~nm}$ and $280 \mathrm{~nm}$ provides an estimate of the purity of the isolated nucleic acid.

\section{DNase I treatment of RNA}

Total RNA isolated using Trizol ${ }^{\mathrm{TM}}$ reagent was treated with RNase free DNase 1 (Fermentas, USA), before cDNA synthesis to remove DNA contamination. The reaction mixture was prepared by adding $2500 \mathrm{ng} / \mu \mathrm{l}$ of total RNA, $2 \mu \mathrm{l}$ of $10 \mathrm{X}$ reaction buffer, $2.5 \mu \mathrm{L}$ DNase I in a PCR tube. The final volume was made to $18 \mu \mathrm{L}$ with nuclease- free water. This reaction mixture was incubated for $30 \mathrm{~min}$ at $37^{\circ} \mathrm{C}$ in a thermal cycler (Applied biosystems,
USA). The reaction was terminated by adding $2 \mu \mathrm{l}$ of $50 \mathrm{mM}$ EDTA followed by a $10 \mathrm{~min}$ incubation at $65^{\circ} \mathrm{C}$.

Complementary DNA (cDNA) preparation and checking the quality of cDNA by L. rohita $\beta$-actin gene amplification in PCR

The mRNA pool was converted to its complementary DNA using the Revert Aid reverse transcriptase First Strand cDNA Synthesis kit (Thermo Scientific, USA) as per the manufacturer's instructions. Briefly, $1 \mu \mathrm{g}$ of the DNase-treated RNA sample was diluted up to $10 \mu 1$ with nuclease free water and mixed with $1 \mu$ l of oligo-dT primer in a PCR tube.

This mixture was incubated at $65^{\circ} \mathrm{C}$ for 5 minutes in a thermal cycler and immediately chilled on ice for 5 minutes. The reaction volume was made up to $20 \mu \mathrm{l}$ by adding $4 \mu \mathrm{l}$ of $5 \mathrm{X}$ reaction buffer, $2 \mu \mathrm{l}$ of dNTP mix (10 $\mathrm{mM}$ each dNTP), $1 \mu \mathrm{l}$ of RiboLock RNase inhibitor (20 units $/ \mu \mathrm{l}$ ) and $2 \mu \mathrm{l}$ of Revert Aid M-MuLV Reverse Transcriptase enzyme (20 units/ $\mu \mathrm{l})$, mixed gently by tapping, spun and incubated at $37^{\circ} \mathrm{C}$ for $60 \mathrm{~min}$. The reaction was terminated by deactivating the enzyme at $70^{\circ} \mathrm{C}$ for $5 \mathrm{~min}$. The quality of synthesized first strand cDNA was checked by amplifying with rohu $\beta$-actin gene using specific primers designed from the sequences of rohu $\beta$-actin gene (Table 2).

\section{Quantification and normalisation of cDNA concentration}

The concentration of the cDNA was measured using Nanodrop spectrophotometer (Thermo Scientific, USA). Nucleic acid concentration was obtained directly in terms of $\mathrm{ng} / \mu \mathrm{l}$ along with the 260:280 ratios. The ratio of the absorbance at $260 \mathrm{~nm}$ and $280 \mathrm{~nm}$ provides an estimate of the purity of the isolated nucleic acid. The cDNA concentration of all the samples was then normalized by diluting to a final concentration of $750 \mathrm{ng} / \mu \mathrm{l}$. 


\section{Designing of Real time primers for TLR22 gene}

Real time primers for TLR22 gene of Labeo rohita was designed using Primer Express software (version 3.0). Factors such as primer length, \%GC content, melting temperature, annealing temperature, secondary structures were taken into consideration while designing the primer sets. Primers were synthesized commercially by $\mathrm{M} / \mathrm{s}$. Bio Innovations, Bioserve, Hyderabad (India). The primers were reconstituted using TE buffer to make a stock solution of $100 \mathrm{pmol} / \mu \mathrm{l}$ concentration. The stock solution was then diluted to get a working concentration of $25 \mathrm{pmol} / \mu 1$.

\section{Real Time primers}

Real Time PCR analysis of Labeo rohita TLR22 gene.

Real-time PCR was performed with an ABI 7300 real-time PCR system using maxima $R$ SYBR green PCR master mix (2x) (Themo Scientific, USA) (Table 3).

Each reaction was prepared in duplicates to a total volume of $10 \mu \mathrm{l}$ per reaction by adding the following components: maxima R SYBR green PCR master mix (2x) $5 \mu$ forward and reverse Primers $(10 \mathrm{pm})$ each $1 \mu 1$, template cDNA $1 \mu 1$, nuclease free water $3.6 \mu$ l. Each sample was normalized with gene specific beta actin primers.

\section{Blood parameters}

The hemoglobin level of blood was analysed following the Cyanmethemoglobin method using Drabkins Fluid (Qualigens).

Total leucocyte count (TLC) was analysed using Neubauer's counting chamber of haemocytometer and observing under under 40X magnification of light microscope.

\section{Albumin/globulin ratio}

Serum protein was estimated by Biuret method (Renhold, 1953) using Innoline ${ }^{\mathrm{TM}}$ Total Protein Plus kit. Thereafter, albumin was estimated by Bromocresol green binding method (Doumas and Biggs, 1972). Albumin in a buffered medium binds with Bromocresol green (BCG) and produces a green colour whose absorbance is proportional to the albumin concentration. Globulin was calculated by subtracting albumin values from total plasma protein.A/G ratio was calculated by dividing albumin values by globulin values

A $/ \mathrm{G}$ ratio $=\frac{\text { Albumin }(\mathrm{g} \%)}{\text { Globulin (g\%) }}$

\section{Challenge study}

After immunomodulation trial through feed over 45 days duration, the fish in various experimental groups were challenged with the pathogenic isolates of Aeromonas hydrophila. For this, the pathogenic isolates of $A$. hydrophila were grown on nutrient agar for 24 $\mathrm{hr}$ at $30^{\circ} \mathrm{C}$ in a BOD incubator. The cells were harvested and washed thrice in sterile PBS and then re suspended in PBS at concentration of $10^{5}$ cells $\mathrm{ml}^{-1}$. The fishes in each experimental group were injected with $0.2 \mathrm{ml}$ of this suspension intra-peritoneally. The cumulative mortality (\%) patterns were observed in the challenged fishes up to a week along with the changes in behaviour and morphology. The cause of death was ascertained by re-isolating the infecting organism from dead fish liver.

At the end of the week of post-challenge, sera and blood samples of different challenged groups were collected to study the immunohaematological parameters of challenged fishes. Liver and gill tissue of representative sample fish (moribund/dead) from control and 
each test group were removed and examined for oxidative stress enzyme activity.

\section{Statistical analysis}

The data were statistically analyzed by using statistical package SPSS version 22 in which data were subjected to one way ANOVA and Duncan's multiple range tests was used to determine the significant differences between the means. Paired t-test was also used to determine the significant difference among the mean of pre and post-challenge condition. Comparisons were made at the $5 \%$ probability level.

\section{Results and Discussion}

\section{DPPH (2，2-Diphenyl-1-picrylhydrazyl) radical scavenging}

The free radical scavenging capacity of the crude fucoidan extracts with different concentrations was tested using the stable free radical, DPPH. The ability of each concentration of fucoidan to scavenge DPPH radical is represented as percentage inhibition (Table 4). The crude extract exhibited varying degrees of scavenging capacity depending on the concentration.

\section{Expression Study of TLR22 gene}

Expression of TLR22 gene in liver was observed in all experimental groups in both pre and post challenge conditions. In prechallenge condition, gene expression was studied on the $45^{\text {th }}$ day of feeding trial. It was found that in treatment group 6 the fold changes in expression of TLR22 gene in liver is significantly higher than other treatment groups.

In post-challenge condition, expression of the gene in liver was observer on the $15^{\text {th }}$ day of challenge by Aeromonas hydrophila.
Treatment groups T6 and T4 showed significantly higher expression of TLR22 gene in liver than other treatment groups.

\section{Serum albumin/globulin (A/G) ratio}

Serum $A / G$ ratio was determined for both the pre and post-challenge periods. In both the periods, the lowest $\mathrm{A}: \mathrm{G}$ ratio was observed in the T4 and T6 group $(0.48 \pm 0.03$ and $0.57 \pm 0.04 ; \quad 0.51 \pm 0.01$ and $0.56 \pm 0.02$ respectively), whereas the highest $\mathrm{A} / \mathrm{G}$ ratio was found in the control $(0.84 \pm 0.02$ and $0.92 \pm 0.01)$ group. Post-challenge values were consistently higher than their pre-challenge counterpart (Fig. 1, 2 and 3).

\section{Total leucocyte count (TLC)}

The pre-challenge and post-challenge TLC of the different treatment groups are given in Table 5. In both the periods, TLC of control group was significantly $(\mathrm{p}<0.05)$ lower than other treatment groups except T2. Highest TLC was found in T6 and lowest in control group in both pre and post-challenge conditions.

\section{Relative survival (\%) and relative survival rate $(\%)$}

The relative survival and survival rate of Labeo rohita after challenge with Aeromonas hydrophilla in different experimental groups are presented in Table 6 . The lowest survival was observed in the control group $(30 \%)$, whereas highest survival rate was recorded in T6 group (70\%). The highest relative survival rate was also recorded in the T6 group (57\%) after challenged with Aeromonas hydrophilla. Toll-like receptors (TLR) act as pattern recognition receptors (PRRs) to sense conserved pathogenic components, known as pathogens-associated molecular patterns (PAMPs) that are essential for their survival (Akira et al., 2006). One of TLRs detected in 
fish, TLR22, but absent in mammals in functional form, is interesting because its activity has been up-regulated with respect to both gram negative bacterial and viral infections (Ikuo et al., 2004; Roach et al., 2005; Rebl et al., 2010). TLR22 is also believed to be associated with innate immunity against ectoparasite infection (Panda et al., 2014).

In this study, expression of TLR22 gene in liver was observed on the $45^{\text {th }}$ day of feeding trial and on the $15^{\text {th }}$ day of challenge by
Aeromonas hydrophila. In the pre-challenge condition, expression of this gene was found to be significantly higher in T6 group. After the challenge with A. hydrophila, expression of TLR22 was observed to be significantly higher in T6 and T4 groups. So, it can be concluded that $2 \%$ fucoidan rich extract and probiotic act synergistically which upregulated of the gene. Prabu et al., (2014) observed higher expression of interferon gamma gene (IFN- $\gamma$ ) in the head kidney of Pangasianodon hypophthalmas fed with fucoidan enriched diet (Fig. 4).

Table.1 Composition of the experimental diets (\% DM basis)

\begin{tabular}{|c|c|c|c|c|c|c|c|}
\hline Ingredients & Control & T1 & T2 & T3 & T4 & T5 & T6 \\
\hline Casein & 33 & 33 & 33 & 33 & 33 & 33 & 33 \\
\hline Gelatin & 7.25 & 7.25 & 7.25 & 7.25 & 7.25 & 7.25 & 7.25 \\
\hline Dextrin & 16.75 & 16.75 & 16.75 & 16.75 & 16.75 & 16.75 & 16.75 \\
\hline Starch soluble & 19.5 & 19.5 & 19.5 & 19.5 & 19.5 & 19.5 & 19.5 \\
\hline Cellulose & 11 & 9 & 11 & 10 & 9 & 10 & 9 \\
\hline Cod liver oil & 4 & 4 & 4 & 4 & 4 & 4 & 4 \\
\hline Sunflower oil & 4 & 4 & 4 & 4 & 4 & 4 & 4 \\
\hline Vit-min premix & 2 & 2 & 2 & 2 & 2 & 2 & 2 \\
\hline CMC & 1.5 & 1.5 & 1.5 & 1.5 & 1.5 & 1.5 & 1.5 \\
\hline BHT & 0.1 & 0.1 & 0.1 & 0.1 & 0.1 & 0.1 & 0.1 \\
\hline $\begin{array}{c}\text { Choline } \\
\text { chloride }\end{array}$ & 0.9 & 0.9 & 0.9 & 0.9 & 0.9 & 0.9 & 0.9 \\
\hline $\begin{array}{c}\text { Fucoidan } \\
\text { Dosage of } \\
\text { probiotic } \\
\text { (CFU g-1 }\end{array}$ & 0 & 2 & 0 & 1 & 2 & 1 & 2 \\
\hline $\begin{array}{c}\text { Total } \\
\text { Nil }\end{array}$ & $\mathbf{1 0 0}$ & $\mathbf{1 0 0}$ & $10^{8}$ & $10^{5}$ & $10^{8}$ & $10^{5}$ & $10^{8}$ \\
\hline
\end{tabular}

Table.2

\begin{tabular}{|c|c|c|}
\hline Gene & Primer & Sequence \\
\hline $\begin{array}{c}\boldsymbol{\beta} \text {-actin } \\
(\mathbf{1 5 0 b p})\end{array}$ & $\boldsymbol{\beta}$-actin $-\mathrm{F}$ & GACTTCGAGCAGGAGATGG \\
\cline { 2 - 3 } & $\boldsymbol{\beta}$-actin $-\mathrm{R}$ & CAAGAAGGATGGCTGGAACA \\
\hline
\end{tabular}


Table.3

\begin{tabular}{|c|c|c|c|}
\hline Gene (Accession No.) & Primer & Sequence & Amplicon Size \\
\hline $\begin{array}{c}\text { Toll like receptor22 } \\
\text { (TLR22) } \\
(\text { KC953875.1) }\end{array}$ & TLR22 -qF & CAGGTGGCGAGCTTCAGACT & 134bp \\
\cline { 2 - 3 } & TLR22 -qR & CGGAGGTAGGTTCGTTTCTTCA & \\
\hline
\end{tabular}

Table.4 Antioxidant assays of Sargassum wightii extracts of different concentrations (DPPH, \% inhibition)

\begin{tabular}{|c|c|c|c|}
\hline $\begin{array}{c}\text { Concentrations } \\
(\mathbf{m g} / \mathbf{m l})\end{array}$ & $\begin{array}{c}\text { DPPH (\% } \\
\text { inhibition) }\end{array}$ & $\begin{array}{c}\text { Concentrations } \\
\text { (mg/ml) }\end{array}$ & $\begin{array}{c}\text { DPPH ( \% } \\
\text { inhibition) }\end{array}$ \\
\hline $\mathbf{0 . 2 5}$ & $9.81 \pm 1.48$ & $\mathbf{6}$ & $42.00 \pm 0.98$ \\
\hline $\mathbf{0 . 5}$ & $13.01 \pm 0.93$ & $\mathbf{8}$ & $50.11 \pm 0.77$ \\
\hline $\mathbf{1}$ & $16.92 \pm 0.62$ & $\mathbf{1 0}$ & $59.35 \pm 0.43$ \\
\hline $\mathbf{2}$ & $21.39 \pm 0.31$ & $\mathbf{1 2}$ & $60.63 \pm 0.63$ \\
\hline $\mathbf{4}$ & $36.74 \pm 1.86$ & & \\
\hline
\end{tabular}

Table.5 Pre and post-challenge TLC of different experimental groups

\begin{tabular}{|c|c|c|}
\hline \multirow{2}{*}{ Treatments } & \multicolumn{2}{|c|}{ TLC $\left(\mathbf{1 0}^{\mathbf{3}} / \mathbf{m m}^{\mathbf{3}}\right)$} \\
\cline { 2 - 3 } & Pre & Post \\
\hline C & $13.33^{\mathrm{aA}} \pm 0.61$ & $15.87^{\mathrm{WA}} \pm 0.78$ \\
\hline T1 & $18.60^{\mathrm{bA}} \pm 0.49$ & $21.63^{\mathrm{XA}} \pm 0.41$ \\
\hline T2 & $12.30^{\mathrm{aA}} \pm 0.83$ & $14.33^{\mathrm{WA}} \pm 0.39$ \\
\hline T3 & $17.23^{\mathrm{bA}} \pm 1.26$ & $19.6^{\mathrm{XA}} \pm 0.32$ \\
\hline T4 & $21.83^{\mathrm{CA}} \pm 0.69$ & $25.5^{\mathrm{yB}} \pm 0.32$ \\
\hline T5 & $19.77^{\mathrm{bcA}} \pm 0.59$ & $21.3^{\mathrm{XA}} \pm 0.91$ \\
\hline T6 & $25.27^{\mathrm{dA}} \pm 1.43$ & $28.27^{2 \mathrm{Z}} \pm 1.48$ \\
\hline
\end{tabular}

Table.6 Survival rate (\%) and relative survival rate (\%) of Labeo rohita fingerlings of different experimental groups challenged with Aeromonas hydrophilla

\begin{tabular}{|c|c|c|}
\hline Treatments & Survival rate (\%) & $\begin{array}{c}\text { Relative survival rate } \\
\text { (\%) }\end{array}$ \\
\hline C & 30 & 00 \\
\hline T1 & 50 & 29 \\
\hline T2 & 40 & 14 \\
\hline T3 & 40 & 14 \\
\hline T4 & 60 & 43 \\
\hline T6 & 50 & 29 \\
\hline & 70 & 57 \\
\hline
\end{tabular}


Fig.1 Fold changes in expression of TLR22 gene in liver on $45^{\text {th }}$ day of feeding trial in different experimental groups

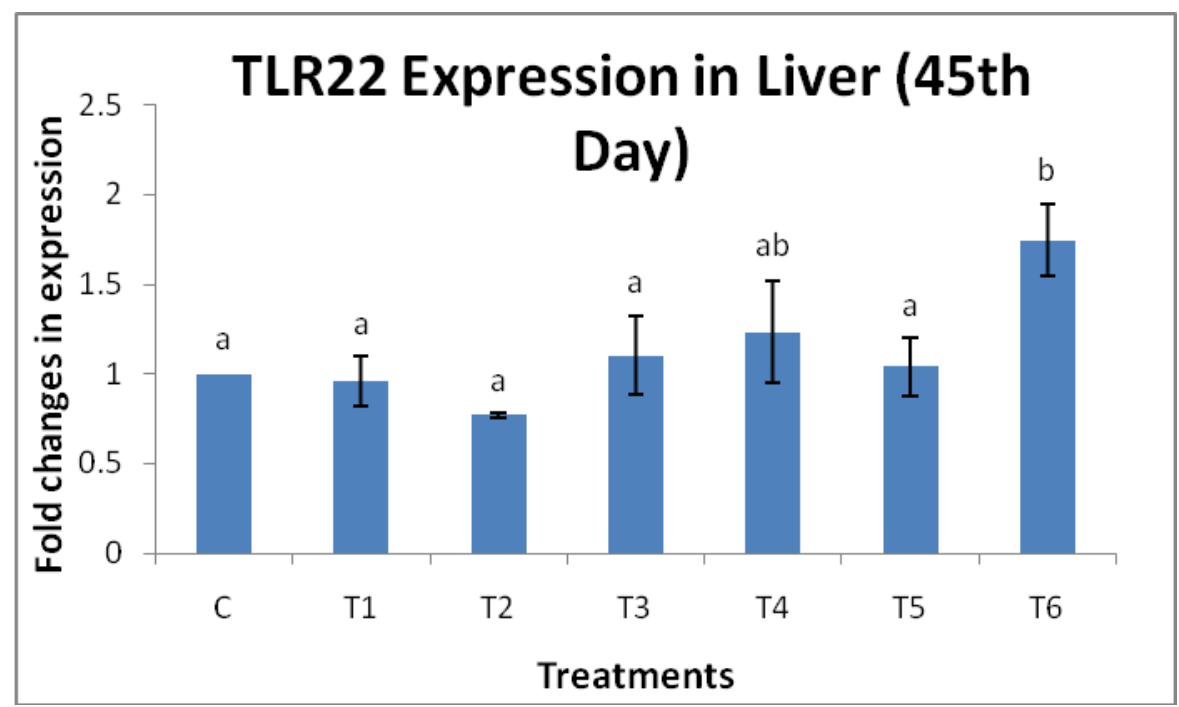

Fig .2 Fold changes in expression of TLR22 gene in liver on $15^{\text {th }}$ day of challenge by Aeromonas hydrophila in different experimental groups

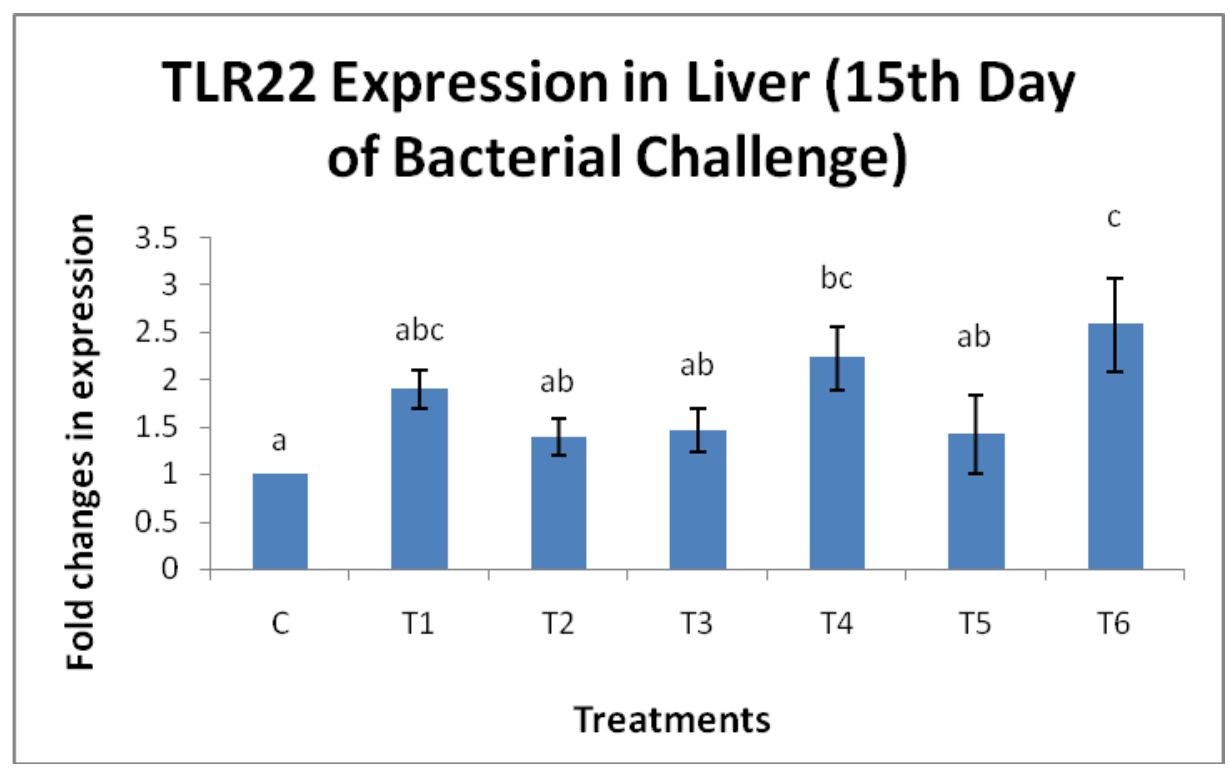


Fig.3 Pre and post-challenge A/G ratio of Labeo rohita fingerlings fed with different experimental diets

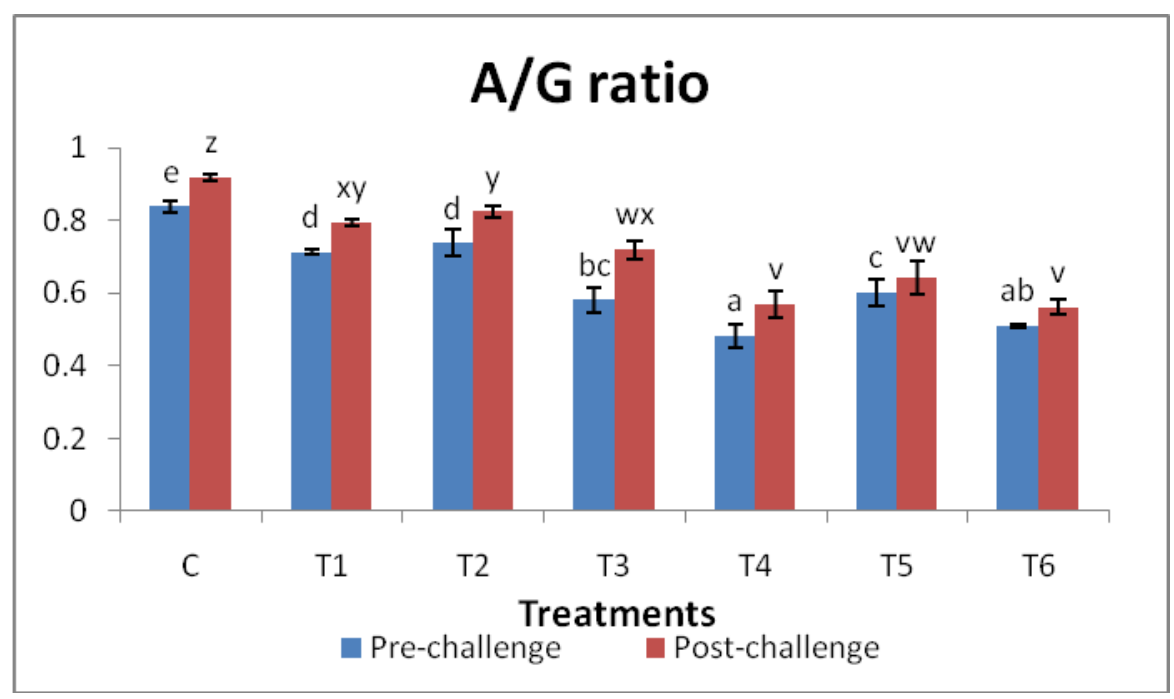

Fig.4 Relative survival rate (\%) of Labeo rohita fingerlings of different experimental groups challenged with Aeromonas hydrophilla

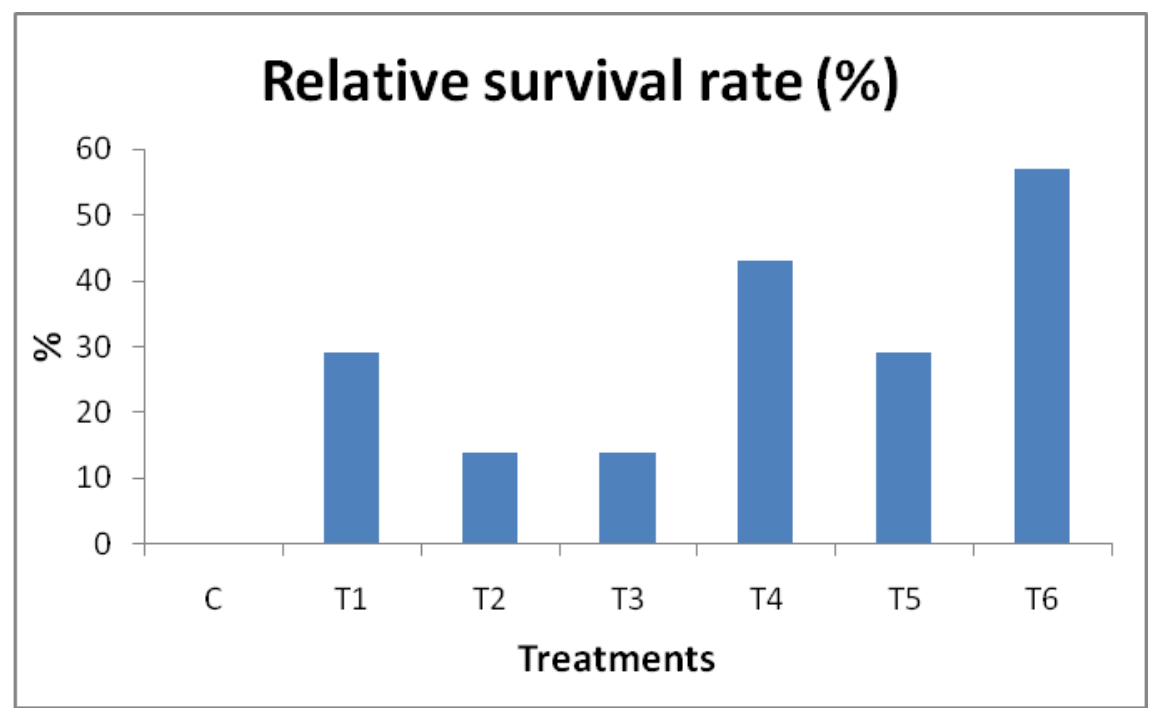

Aeromonas hydrophila is a gram negative motile bacteria pathogen of the family Aeromonadaceae. It is one of the major pathogen widely distributed in aquatic environments causing infectious dropsy, fin rot, haemorrhagic septicaemia and epizootic ulcerative syndrome in both freshwater (Shao et al., 2004) and marine species (Lilley et al., 1997) leading to high mortality in aquaculture farms. The serum proteins are categorized into two groups, albumin and globulins. Again serum globulin consists of several components among which groups can be identified as alpha, beta and gamma globulin. The gamma globulin fraction is the source of almost all the immunologically active proteins of the blood. So, globulins like gamma globulins are absolutely essential for maintaining a healthy 
immune system. Increase in the globulin level is thought to be associated with a stronger innate immunity in fishes (Wiegertjes et al., 1996). All the treatment groups were found to have significantly lower $\mathrm{A} / \mathrm{G}$ ratio than the control, with lowest in T4 and T6 groups.

The values of total leucocyte count differed significantly among the experimental groups in both pre and post challenge conditions.

All the treatment groups except T2 were found to have significantly higher leucocyte count in blood; which is associated with strengthening of immunity, among which value of T6 group was highest followed by $\mathrm{T} 4$ in both pre and post challenge conditions.

In the present study, the highest relative rate of survival was observed in T6 group followed by $\mathrm{T} 4$ group. Both these groups were fed with diet containing both fucoidan (at 2\% level) and probiotic. All the experimental groups showed higher survival rate compared to the control. This might be due the triggering of the non-specific immune system of the fish by the synergistic effect of fucoidan extract and probiotic bacteria. This can be correlated with higher expression of TLR22 gene in those groups.

It has found that the combination of fucoidan (at $2 \%$ inclusion) and probiotic bacteria (at $10^{8}$ CFU $\mathrm{g}^{-1}$ dosage) can promote the upregulation of TLR22 gene. But if the fish is already affected by pathogenic gram-negative bacteria then fucoidan (at $2 \%$ ) with a lower dose of probiotic $\left(10^{5} \mathrm{CFU} \mathrm{\textrm {g } ^ { - 1 } )}\right.$ may also cause significant up-regulation of the gene. Combination of fucoidan and probiotic will be an ideal approach to fish in achieving a significantly higher non specific immunity.

\section{References}

Adnan (2014) Expression of defensin gene and immunomodulatory response of Labeo rohita fed with fucoidan rich seaweed extract. Thesis M.F.Sc., ICAR- Central Institute of Fisheries Education

Akira, S., Uematsu, S. and Takeuchi, O., 2006. Pathogen recognition and innate immunity. Cell, 124(4):783-801.

Alexander J B, Ingram G A (1992) Noncellular nonspecific defense mechanism of fish. Annu Rev Fish Dis 2:249-279

Aly S M, Ahmed Y A G, Ghareeb A A, et al., (2008). Studies on Bacillus subtilis and Lactobacillus acidophilus, as potential probiotics, on the immune response and resistance of Tilapia nilotica (Oreochromis niloticus) to challenge infections. Fish Shellfish Immunol 25(12):128-136

Anderson D P, Siwicki A K (1995) Basic haematology and serology for fish health programmes, In: Diseases in Asian Aquaculture II (ed. Shharif, M., Arthur, J. R. and Subashinge, R.P.). Fish Health section, Asian fisheries society, Manilla, Phillipines, pp. 185-202

Brand-Williams, W., Cuvelier, M. E. and Berset, C., 1995. Use of a free radical method to evaluate antioxidant activity. Food Sci. Technol., 28: 25-30

Canciyal J, Jawahar P, Mogalekar H S, et al.,(2016). Effect of seaweed extracted fucoidan on enhancement of the immune response of giant freshwater prawn Macrobrachium rosenbergii.

Chotigeat W, Tongsupa S, Supamataya K, et al., (2004) Effect of fucoidan on disease resistance of black tiger shrimp. Aquaculture 233:23-30

Doumas B T, Biggs H G (1972) Determination of serum albumin. Stand Method. Clin Chem Acad Press New york 7:175

Doumas, B. T. and Biggs, H. G., 1972. Determination of serum albumin. Stand. Method Clin. Chem., Acad. Press, New york., 7:175.

Dubois M, Gilles K A, Hamilton J K, et al., (1956) Colorimetric method for determination of sugars and related substances. Anal Chem.28:350-56

Dubois, M., Gilles, K. A., Hamilton, J. K., 
Rebers, P. A. and Smith, F., 1956. Colorimetric method for determination of sugars and related substances. Anal. Chem., 28:350-56.

Gora AH, Sahu NP, Sahoo S, et al., (2018) Effect of dietary Sargassum wightii and its fucoidan-rich extract on growth, immunity, disease resistance and antimicrobial peptide gene expression in Labeo rohita. International Aquatic Research, pp.1-17.

Isnansetyo A, Fikriyah A, Kasanah N (2016). Non-specific immune potentiating activity of fucoidan from a tropical brown algae (Phaeophyceae), Sargassum cristaefolium in tilapia (Oreochromis niloticus). Aquacult In 24(2): 465-477

Lee M, Shiau S (2004) Vitamin E requirement in Juvenile grass shrimp, Penaeus monodon and effect on non-specific immune responses. Fish Shellfish Immunol 16: 475-485

Lilley, J. H., Hart, D., Richards, R. H., Roberts, R. J., Cerenius, L. and Soderhall, K., 1997. Pan-Asian spread of single fungal clone results in large-scale fish kills. Vet. Res., 140:653-654.

Misra H P, Frodovich I (1972) The role of superoxide anion in the autooxidation of epinephrine and a simple assay for SOD. J Biol Chem, 247:3179-3175

Mohapatra S, Chakraborty T, Kumar V, et al., (2013). Aquaculture and stress management: a review of probiotic intervention. J Anim Physiol An N 97(3): 405-430

Nelson N (1944). A photometric adaptation of the Somogyi method for the determination of glucose. J Biol Chem 153:374-380

Newaj-Fyzul A, Adesiyun A A, Mutani A, et al., (2007). Bacillus subtilis AB1 controls Aeromonas infection in rainbow trout (Oncorhynchus mykiss, Walbaum). J Appl Microbiol 103(5):1699-1706

Olmos J, Paniagua-Michel,J (2014) Bacillus subtilis a potential probiotic bacterium to formulate functional feeds for aquaculture. Microb \& Biochem Technol, 6(7); 361-365.

Prabu D L, Sahu N P, Pal A K, et al., (2014) Immunomodulation and interferon gamma gene expression in sutchi cat fish, Pangasianodon hypophthalmus: effect of dietary fucoidan rich seaweed extract (FRSE) on pre and post challenge period. Aquacultr Res 47(1):120

Prabu D L, Sahu N P, Pal A K, et al., (2016). Immunomodulation and interferon gamma gene expression in sutchi cat fish, Pangasianodon hypophthalmus: effect of dietary fucoidan rich seaweed extract (FRSE) on pre and post challenge period. Aquac Res 47(1): 199218

Prabu, D. L., Sahu, N. P., Pal, A. K., Dasgupta, S and Narendra, A., 2014. Immunomodulation and interferon gamma gene expression in sutchi cat fish, Pangasianodon hypophthalmus: effect of dietary fucoidan rich seaweed extract (FRSE) on pre and post challenge period. Aquacultr. Res., 47(1):1-20.

Quade M J, Roth J A (1997) A rapid, direct assay to measure degralution of bovine neutrophil primary granules. Vet Immunol Immunopathol 58:239- 248

Raida M K, Larsen J L, Nielsen M E, et al., (2003). Enhanced resistance of rainbow trout, Oncorhynchus mykiss (Walbaum), against Yersinia ruckeri challenge following oral administration of Bacillus subtilis and B. licheniformis (BioPlus2B). J Fish Dis 26(8) 495-498

Rebl, A., Goldammer, T. and Seyfert, H.M., 2010. Toll-like receptor signaling in bony fish. Vet. Immunol. Immunopathol., 134(3):139-150.

Renhold, J. G., 1953, Manual determination of serum total protein, albumin and globulin fraction by Biuret method. In: Standard method of clinical chemistry (ed. Reiner, M.). Acadmic Press, New York, pp 88.

Ringo E, Schillinger U, Holzapfel W (2005) 
Antimicrobial activity of lactic acid bacteria isolated from aquatic animals and the use of lactic acid bacteria in aquaculture. Biology of growing animals 2:418-453

Roach, J. C., Glusman, G., Rowen, L., Kaur, A., Purcell, M. K., Smith, K. D., Hood, L. E. and Aderem, A., 2005. The evolution of vertebrate Toll-like receptors. Proceedings of the National Academy of Sciences of the United States of America, 102(27): 9577-9582.

Secombes C J, Fletcher T C (1992) The role of phygocytes in protective mechanisms of fish. Annual Rev of Fish Dis 2:53-71

Shao, J., Liu, J. and Xiang, L., 2004. Aeromonas hydrophila induces apoptosis in Carassius auratus lymphocytes in vitro. Aquaculture, 229:11-23.

Silas, E. G., Chenn, V. S. K. and Kaliaperumal, N., 1986. Seaweed resources, products and utilisation. Seaweed Res. Utilisat., 9:11-24.

Sinurat E, Saepudin E, Peranginangin R, et al.,(2016) Immunostimulatory activity of brown seaweed-derived fucoidans at different molecular weights and purity levels towards white spot syndrome virus (WSSV) in shrimp Litopenaeus vannamei. J Appl Pharma Sc 6(10) 082091

Sony $\mathrm{N}$ M, Ishikawa M, Hossain M., Et al.,(2018) The effect of dietary fucoidan on growth, immune functions, blood characteristics and oxidative stress resistance of juvenile red sea bream, Pagrus major. Fish Physiol Biochem 116

Stasiak A S, Bauman C P (1996) Neutrophil activity as a potent indicator of concomitant analysis. Fish Shellfish Immunol 37:539

Takhara S, Hamiton, H B, Neel J V, et al., (1960) Hypoctalasemia, a new genetic carrier state. J Clin Invest 39:610-619

Tuller J, Santis D C, Jerry R D (2012) Dietary influence of Fucoidan supplementation on growth of Lates calcarifer (Bloch). Aqua Res 1-6

Vaseeharan B A R P, Ramasamy P (2003). Control of pathogenic Vibrio spp. by Bacillus subtilis BT23, a possible probiotic treatment for black tiger shrimp Penaeus monodon. Lett Appl Microbiol36(2): 83-87

Weeks B, Warinner J E (1986). Functional evaluation of macrophages in fish from a polluted estuary. Vet Immunol Immunopathol 2:313-320

Wiegertjes G F, Stet R M, Parmentier H K, et al., (1996). Immunogenetics of disease resistance in fish: a comparative approach. Dev Comp Immunol 20(6): 365-381

Wiegertjes, G. F., Stet, R. M., Parmentier, H. K. and Van Muiswinkel, W. B., 1996. Immunogenetics of disease resistance in fish: a comparative approach. Dev. Comp. Immunol., 20(6):365-381.

\section{How to cite this article:}

Ghoshal, R. and Sahu, N.P. 2019. Expression of TLR-22 Gene and Response of Non Specific Immunity of Labeo rohita Fed with Fucoidan Rich Seaweed Extract in Conjugation with Bacillus subtilis. Int.J.Curr.Microbiol.App.Sci. 8(11): 347-361. doi: https://doi.org/10.20546/ijcmas.2019.811.044 